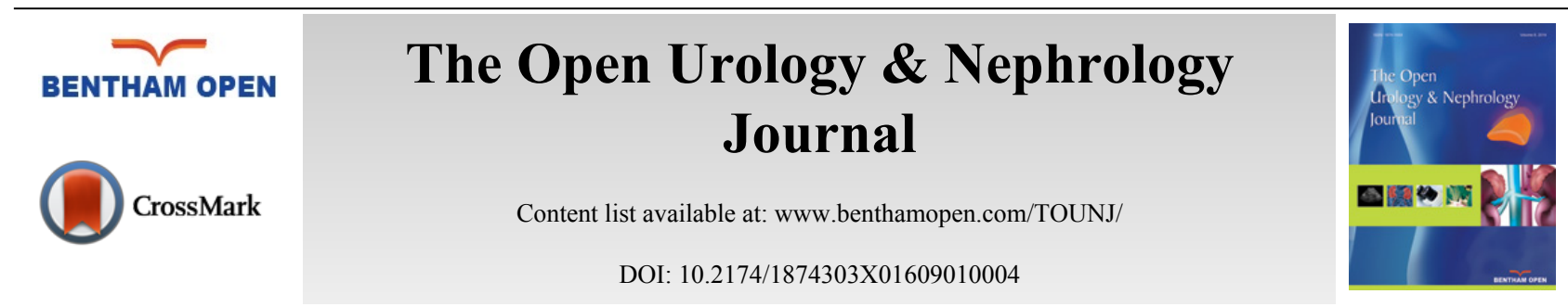

\title{
LEARNING FROM IMAGES Fundamental Mistake During Tunneled Hemodialysis Catheter (TDC) Removal
}

\author{
Michael J. Kelly ${ }^{1}$, Siddiq Anwar ${ }^{1}$, Tushar Vachharajani ${ }^{2}$, Maciej Karasek ${ }^{1}$ and Saeed Ahmed ${ }^{* 1}$ \\ ${ }^{I}$ Sunderland Royal Hospital, UK \\ ${ }^{2}$ W.G. (Bill) Hefner Veterans Affairs Medical Center, Salisbury, NC, USA
}

Tunneled hemodialysis catheter (TDC) removal is relatively a safe procedure with common complications that include bleeding, soreness and scar. Less common complications of tethering, air embolus, fibrin sheath embolization and pulmonary embolus have been reported $[1,2]$.

62-year-old female with end stage renal disease due to obstructive uropathy initially commenced hemodialysis via a TDC (BIO-FLEX ${ }^{\circledR}$ TESIO $^{\circledR}$ CATH, Medcomp ${ }^{\circledR}$, Harleys-ville, PA) in March 2014. Once her permanent access had matured, 9 months after insertion, a decision was made to remove her TDC.

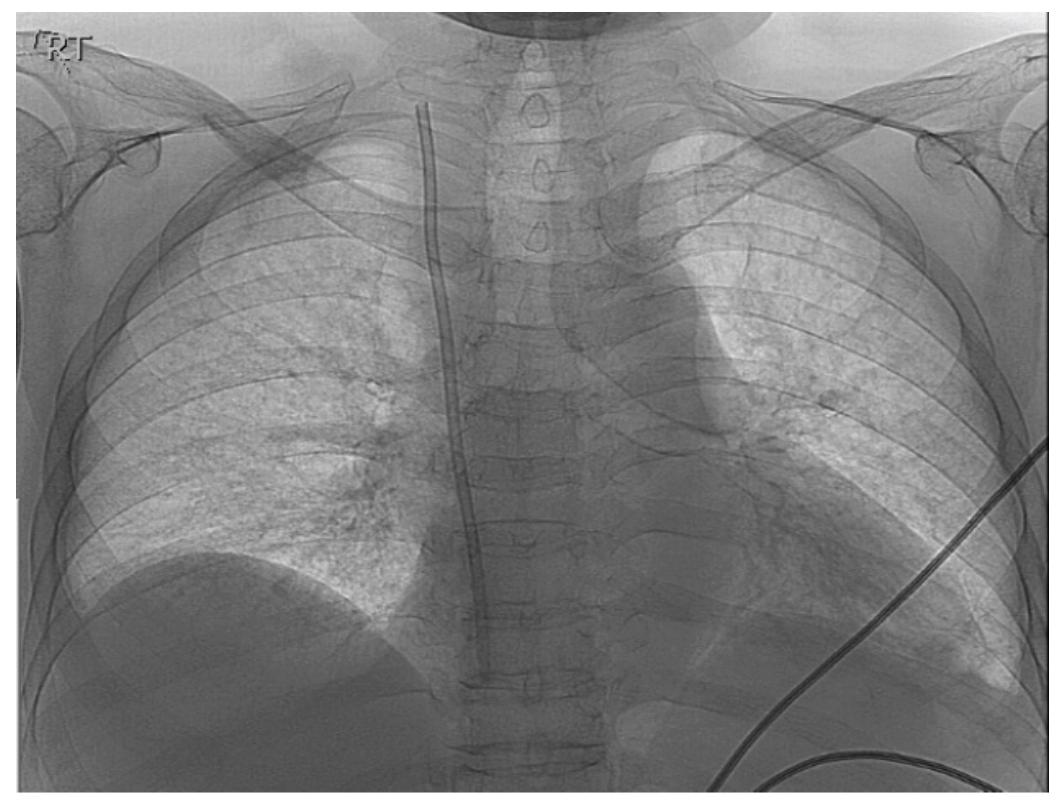

Fig. (1). The proximal segment of the BIO-FLEX ${ }^{\circledR}$ TESIO $^{\circledR}$ CATH seen in the superior vena cava and the right atrium.

After taking aseptic precautions, local anesthetic was infiltrated around the Dacron cuff that tethers these catheters to the skin. A small incision was made on the skin over the cuff. Using blunt dissections both cuffs were mobilized in the subcutaneous tissue. The arterial catheter was easily removed. A significant resistance was encountered while attempting to pull the venous catheter. A decision to cut the catheter above the cuff and attempt further dissection failed

\footnotetext{
* Address correspondence to this author at the Renal Unit, City Hospital, Kayll Rd, Sunderland, Tyne And Wear, SR4 7TP, UK; Tel: +44191 5656256, Ext. 41466; Fax: +44191 5699208; E-mail: Saeed.Ahmed@chsft.nhs.uk
} 
to release the catheter. The proximal segment of the catheter was anchored with a hemostat. Unfortunately, the proximal segment of the catheter further retracted into the tunnel while trying to adjust the forceps. Pressure was applied over the clavicle and the incision was extended up the tunnel to retrieve the catheter. The catheter continued to retract and was eventually lost in the right internal jugular vein.

An urgent X-Ray revealed the catheter segment positioned in the superior vena cava (Fig. 1). The patient was transferred to the fluoroscopy suite and the severed segment of the catheter was retrieved using a snare device introduced via femoral vein (Fig. 2). There were no long-term complications.

This case highlights the importance of maintaining the integrity of the TDC and the potential complication that can result from cutting the proximal portion of TDC during its removal. A safer technique to separate a tightly tethered cuff is to perform dissection under direct vision rather than using tactile sensation alone.

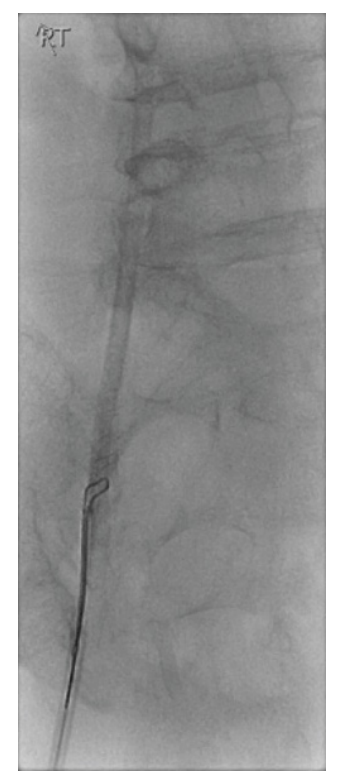

Fig. (2). The snare device deployed over the shaft of the catheter and removed via the femoral vein.

\section{CONFLICT OF INTEREST}

The authors confirm that this article content has no conflict of interest.

\section{ACKNOWLEDGEMENTS}

Declared none.

\section{REFERENCES}

[1] Ndzengue A, Kessaris N, Dosani T, Mustafa N, Papalois V, Hakim NS. Mechanical complications of long-term Tesio catheters. J Vasc Access 2009; 10(1): 50-4. [PMID: 19340800]

[2] Oguzkurt L, Ozkan U, Torun D, Tercan F. Does a fibrin sheath formed around a catheter embolize upon removal of the catheter? Nephrol Dial Transplant 2007; 22(12): 3677-9. [http://dx.doi.org/10.1093/ndt/gfm536] [PMID: 17898022]

Received: February 20, $2015 \quad$ Revised: August 2, 2015 Accepted: August 26, 2015

(C) Kelly et al.; Licensee Bentham Open.

This is an open access article licensed under the terms of the Creative Commons Attribution-Non-Commercial 4.0 International Public License (CC BY-NC 4.0) (https://creativecommons.org/licenses/by-nc/4.0/legalcode), which permits unrestricted, non-commercial use, distribution and reproduction in any medium, provided the work is properly cited. 